Term Care Committee. Antimicrobial use in long-term care facilities. Infect Control Hosp Epidemiol 1996;17:119-128.

16. Nicolle LE, Strausbaugh IJ, Garibaldi RA. Infections and antibiotic resistance in long-term care facilities. Clin Microbiol Rev 1996;9:1-17.

17. Strausbaugh LJ, Joseph C. Epidemiology and prevention of infections in residents of long-term care facilities. In: Mayhall CG, ed. Hospital Epidemiology and Infection Control. Baltimore, MD: Williams and Wilkins; 1996:1151-1170.

18. Zimmer JG, Bentley DW, Valenti WM, Watson NM. Systemic antibiotic use in nursing homes. J Am Geriatr Soc 1986;34:703-710.

19. Jones SR, Parker DF, Liebow ES, Kimbrough RC, Frear RS. Appropriateness of antibiotic therapy in long-term care facilities. Am JMed 1987;83:499-502.

20. Metlay JP, Kapoor WN, Fine MJ. Does this patient have communityacquired pneumonia? Diagnosing pneumonia by history and physical examination. JAMA 1997;278:1440-1445.

21. Wipf JE, Lipsky BA, Hirschmann JV, Boyko EJ, Takasugi J, Peugeot RL, et al. Diagnosing pneumonia by physical examination: relevant or relic? Arch Intern Med 1999;159:1082-1087.

22. McGeer A, Campbell B, Emori TG, Hierholzer WJ, Jackson MM, Nicolle $\mathrm{LE}$, et al. Definitions of infection for surveillance in long-term care facilities. Am J Infect Control 1991;19:1-7.

23. Jones J, Hunter D. Consensus methods for medical and health services research. BMJ 1995;311:376-380.

24. Orr PH, Peeling RW, Fast M, Brunka J, Duckworth H, Harding GK, et al. Serological study of responses to selected pathogens causing respiratory tract infection in the institutionalized elderly. Clin Infert Dis 1996;23:1240-1245.
25. American Psychiatric Association. Diagnostic and Statistical Manual of Mental Disorders. 4th ed. Washington, DC: American Psychiatric Association; 2000. Text Revision.

26. Ball P, Chodosh S, Grossman R, Tillotson M, Wilson R. Causes, epidemiology, and treatment of bronchial infections. Infect Med $2000 ; 17: 186-189$

27. Wasserman M, Levinstein M, Keller E, Lee S, Yoshikawa TT. Utility of fever, white blood cells, and differential count in predicting bacterial infections in the elderly. J Am Geriatr Soc 1989;37:537-543.

28. Nicolle LE. Asymptomatic bacteriuria in the elderly. Infect Dis Clin North Am 1997;11:647-662.

29. Nicolle LE, Bjornson J, Harding GK, MacDonnell JA. Bacteriuria in elderly institutionalized men. $N$ Engl J Med 1983;309:1420-1425.

30. Nicolle LE, Mayhew JW, Bryan L. Prospective randomized comparison of therapy and no therapy for asymptomatic bacteriuria in institutionalized women. Am J Med 1987;83:27-33.

31. Ouslander JG, Schapira M, Schnelle JF, Uman G, Fingold S, Tuico E, et al. Does eradicating bacteriuria affect the severity of chronic urinary incontinence in nursing home residents? Ann Intern Med 1995; 122:749-754.

32. Abrutyn E, Mossey J, Berlin JA, Boscia J, Levison M, Pitsakis P, et al. Does asymptomatic bacteriuria predict mortality and does antimicrobial treatment reduce mortality in elderly ambulatory women. $A n n$ Intern Med 1994;120:827-833.

33. Cookson BD. The emergence of mupirocin resistance: a challenge to infection control and antibiotic prescribing practice. $J$ Antimicrob Chemother 1998;41:11-18.

\title{
Computer Keyboards and Faucet Handles: Reservoirs of Pathogens in the ICU
}

\section{Gina Pugliese, RN, MS Martin S. Favero, PhD}

Bures and colleagues, believing computer keyboards and faucet handles to be significant reservoirs of nosocomial pathogens in the intensive care unit (ICU), conducted a study to determine if their hypothesis was true. Sterile swab samples were obtained from 10 keyboards and 8 pairs of faucet handles in the medical ICU at Tripler Army Medical Center during a period of 2 months. Methicillin-resistant Staphylococcus aureus (MRSA) obtained from the environmental and patient specimens were identified using pulsed-field gel electrophoresis (PFGE).

A total of 144 samples were obtained (80 keyboards and 64 faucet handles), yielding 33 isolates. The colo- nization rate for keyboards was $24 \%$ for all rooms and $26 \%$ in occupied rooms. Rates for faucet handles in all rooms and occupied rooms were $11 \%$ and $15 \%$, respectively. The environmental isolates and their prevalence were as follows: MRSA, $49 \%$; Enterococcus, 18\%; Enterobacter, 12\%; and all other gram-negative rods, $21 \%$.

Fourteen individual patient isolates were recorded: MRSA, 43\%; Enterobacter, $21 \%$; other gram-negative rods, $36 \%$; and Enterococcus, 0\%. PFGE identified an indistinguishable strain of MRSA in two patients, on the keyboards and faucet handles in their respective rooms, and on other keyboards throughout the ICU, including the doctors' station.

The authors concluded that the colonization rate for keyboards and faucet handles is greater than that of other wellstudied ICU surfaces in rooms with MRSA- positive patients. The findings suggest an associated pattern of environmental contamination and patient infection not limited to the patient's room. PFGE results have documented an indistinguishable strain of MRSA present as an environmental contaminant on these two fomites and in two patients with clinical infections during the same period. They believe these findings support the hypothesis that these particular surfaces may serve as reservoirs of nosocomial pathogens and vectors for crosstransmission in the ICU setting. New infection control policies and engineering plans were initiated on the basis of these results.

FROM: Bures S, Fishbain JT, Uyehara CF, Parker JM, Berg BW. Computer keyboards and faucet handles as reservoirs of nosocomial pathogens in the intensive care unit. Am J Infect Control $2000 ; 28: 465-471$ 